\title{
Relationship between Drought Tolerance and Ageing in Higher Plants I. Mineral Content
}

\author{
by Takeshi TAKAOKI*
}

Received June 25, 1966

In a plant body the younger leaves seem to be more tolerant to drought than the older ones, because the latter begin to wilt early but the former hardly at all when the culture soil drys ${ }^{1)}$. On the other hand, it is conceivable that a plant acquires drought tolerance if it is kept under drought conditions for a long time. In these two instances of developing drought tolerance, as far as the soil moisture deficit or the relative age of leaf are concerned, phenomena in common are the increases of respiration rate and bound-water content of leaf; on the other hand, the osmotic value increases with drying of soil, but is slightly lower in the younger leaves than in the older ones ${ }^{1)}$. In order to determine whether the drought tolerance of leaves developed by drought hardening is the same as that observed in young leaves or not, some comparative studies on the mineral content of leaves were made between different series of leaves, one in relation to the soil moisture and the other to the leaf age.

\section{Materials and Methods}

The seeds of cowpea (Vigna sinensis Endl.) which had been harvested in Hiroshima after culturing of the seeds obtained from The Dune Institute of Tottori University and commerical rape seeds (Brassica rapa L. var. chinensis Kitam.) were sown in soil of adequate moisture content in several pots. After germination the pots were left without irrigation in a green house untill the water content of the soil reached desired levels. Subsequently the soil moistures were held at constant levels in a graduated series by means of daily irrigation, that is, each pot was added with an equivalent amount of water to the weight loss of the pot. Details of the cultural techniques were presented in a previous paper ${ }^{11}$. The soil moisture in this paper is expressed in percentage of the maximum water-holding capacity of the soil, which was estimated previously to be about $27 \%$ of the dry soil. The observations were made at least 20 days after the soil moisture reached the desired level. Fresh weight of the leaf blades was weighed immediately after cutting them off from the plant and the leaves were washed thoroughly with water. After drying at $105^{\circ}$ for 30 minutes they were dried further at $70^{\circ}$ for several days. Then they were weighed, ground into powder, dried again at $70^{\circ}$, and stored in a desiccator. A certain quantity (50-300 mg) of the materials was digested in a Kjeldahl flask with 1.5 to $2.5 \mathrm{ml}$ of digestion reagent consisting of an equal volume of sulfuric and nitric acids After cooling, 0.5 to 1.0 $\mathrm{m} l$ of hydrochloric acid and about $20 \mathrm{~m} l$ of water were added, heated gently for a few minutes and allowed to cool. The digested sample was diluted with deionized water to 50 or $100 \mathrm{ml}$, filtered to remove silica and the filtrate was used for analysis.

Potassium and sodium were analysed by Lange's flame photometer. Preliminary

\footnotetext{
* Botanical Institute, Faculty of Science, Hiroshima University, Hiroshima, Japan.
} 
test for interference of acids added for degestion on flame photometric analysis was performed to correct the observed values.

Calcium and magnesium were analysed by chelatometric titration. Determination of calcium was made as follows: $2 \mathrm{~m} l$ of the digested sample was neutralized with $10 \% \mathrm{NaOH}$ solution, $5 \mathrm{~m} l$ of the $\mathrm{NaOH}$ solution was added in excess, and deionized water was added making the total volume up to about $50 \mathrm{~m} l$. Then 50 to $100 \mathrm{mg}$ of crystalline potassium cyanide and $2 \mathrm{~m} l$ of $5 \%$ sodium sulfide solution were added. After standing at room temperature for over 2 minutes, 50 to $100 \mathrm{mg}$ of NN-reagent ("Dotite NN" of Wako Chem. Ind. Co.) were added, and then titrated with 0.001 M EDTA (ethylenediaminetetraacetic acid disodium salt) solution. Determination of magnesium was as follows: $2 \mathrm{~m} l$ of the digested sample was neutralized with a buffer solution ( $70 \mathrm{~g}$ of $\mathrm{NH}_{4} \mathrm{Cl}$ and $750 \mathrm{~m} l$ of conc. $\mathrm{NH}_{4} \mathrm{OH}$ were mixed and diluted with water to $1000 \mathrm{~m} l), 5 \mathrm{~m} l$ of the buffer solution was added in excess and diluted with deionized water to about $50 \mathrm{~m} l$. Immediately after the successive addition of 50 to $100 \mathrm{mg}$ of crystalline potassium cyanide, $2 \mathrm{~m} l$ of $5 \%$ sodium sulfide solution, and 50 to $100 \mathrm{mg}$ of EBT reagent (a mixed powder, $1 \mathrm{~g}$ eliochrome black $\mathrm{T}$ in $100 \mathrm{~g} \mathrm{KCl}$ ) to the solution, it was titrated with $0.001 \mathrm{M}$ EDTA solution. Magnesium was calculated from difference between the titration value for magnesium and that for calcium.

Phosphorus was analysed by Nakamura's method ${ }^{2)}$ or by Chen-Toribara-Warner's method $^{31}$.

\section{Results}

1) Brassica rapa Cultivation of rape was made twice, the first culture was set on March 24 and the soil moistures of the pots were controlled at $60,43,30,21$, and $15 \%$ of maximum water-holding capacity of the soil. A leaf situated at the middle of leaf order (e.g. the 5th leaf of a plant which has 9 leaves) was selected as the representative of the test plant, and was picked from the plants on May 14 and 25, and the leaves from the same pot were mixed. The second culture was set on Oct. 22 and the soil moistures, were controlled at 100, 60, 38, 24, and 15\%. The leaves attached at the middle of leaf order were picked on Jan. 12, 28, and Feb. 14 and the leaves from the same pot were mixed. Mineral contents of these samples are shown in Fig. 1. In both cases potassium content increased and calcium content decreased with decrease in soil moisture. Magnesium and phosphorus also seemed to be higher in dry plots than in wet ones, but no considerable variation was seen in sodium content.

Fig. 2 shows the sum of cations, total milliequivalents and total millimoles. No remarkable change is seen in the sum of cations since the potassium increase compensates for the decrease of calcium.

2) Vigna sinensis Cultures were made in 3 sowings on April 6, 30, and May 21. The soil moisture was kept at $90,60,41,28,19$, and $13 \%$ in each culture throughout the experiment. All leaves except immature young ones of the test plants were used for the assay. The values of mineral content obtained by several determinations during one culture, were averaged, and these mean values of three cultures were averaged again. The final values are shown on the right side in Fig. 3.

The potassium content increased but calcium decreased inversely and phosphorus increased slightly with the drying of the soil, while the magnesium and sodium contents did not show any considerable change. These results are similar to those of rape plants. 


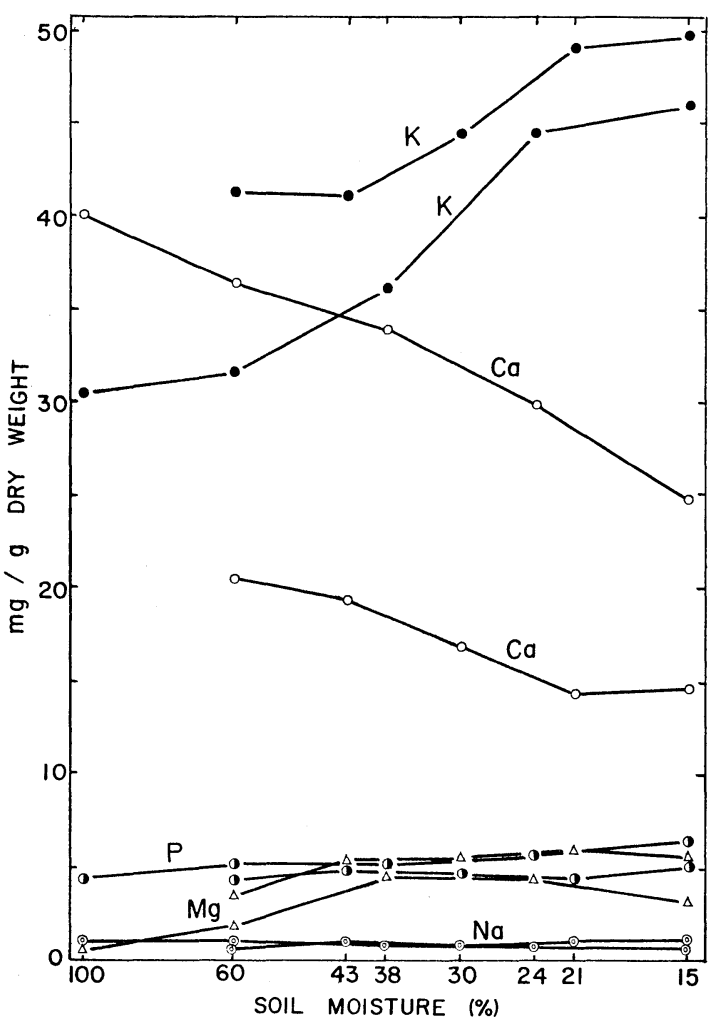

Fig. 1. Mineral content of rape leaves grown under various soil moisture conditions. First culture: $60,43,30,21$, and $15 \%$ soil moisture. Second culture: $100,60,38,24$, and $15 \%$ soil moisture.
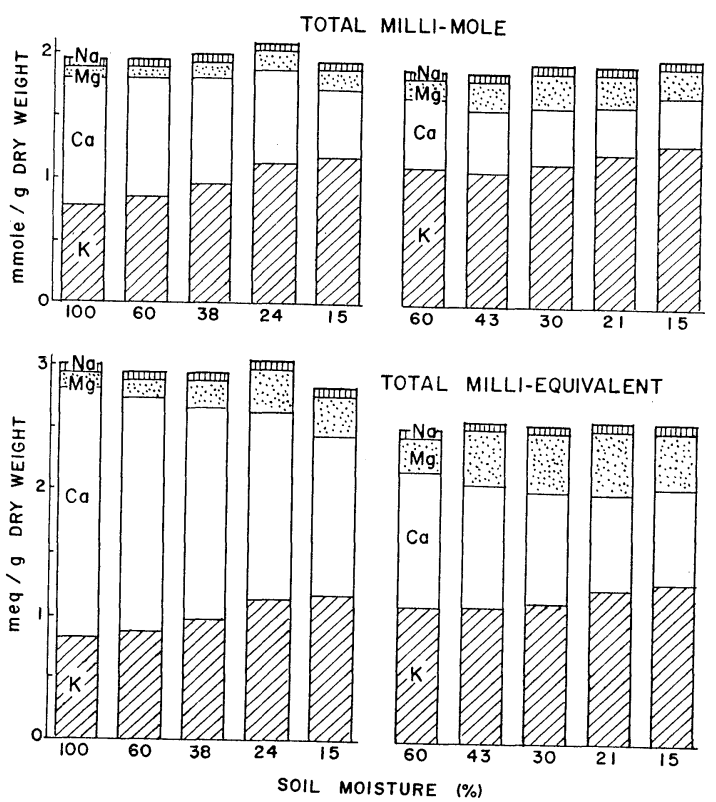

Fig. 2. Total millimoles (upper) and total milliequivalents (lower) of cations of rape leaves cultured under narious soil moisture-conditions. 
On the other hand, all leaves, except immature ones, of other test plants sown on June 20 were picked on Sept. 3, and classified into six groups on the basis of leaf order irrespectively of the cultural soil moisture differences, each group having an equal number of leaves. The mineral contents of these leaves are shown on the left side in Fig. 3. The matured older leaves contained more calcium, less potassium and slightly less phosphorus than the younger ones. No considerable variations were seen
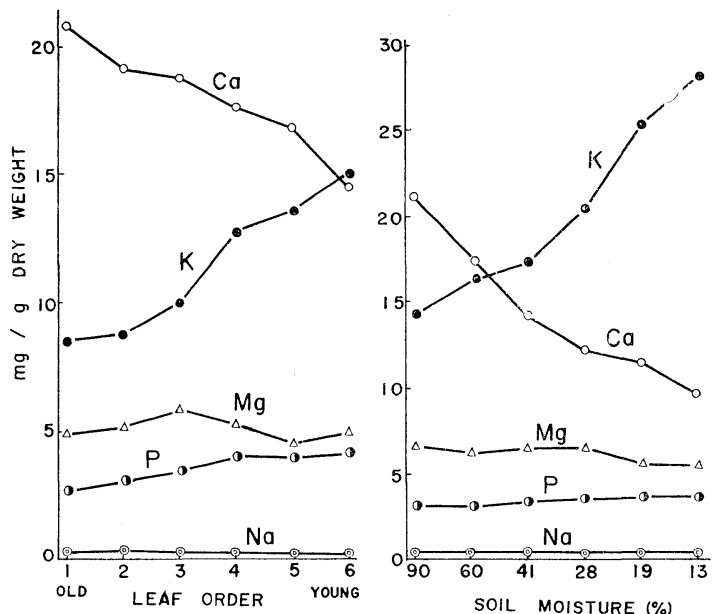

Fig. 3. Variation of mineral content of cowpea leaves in reference to the leaf age (left)and to the cultural soil moisture (right).

TOTAL MILLI-MOLE
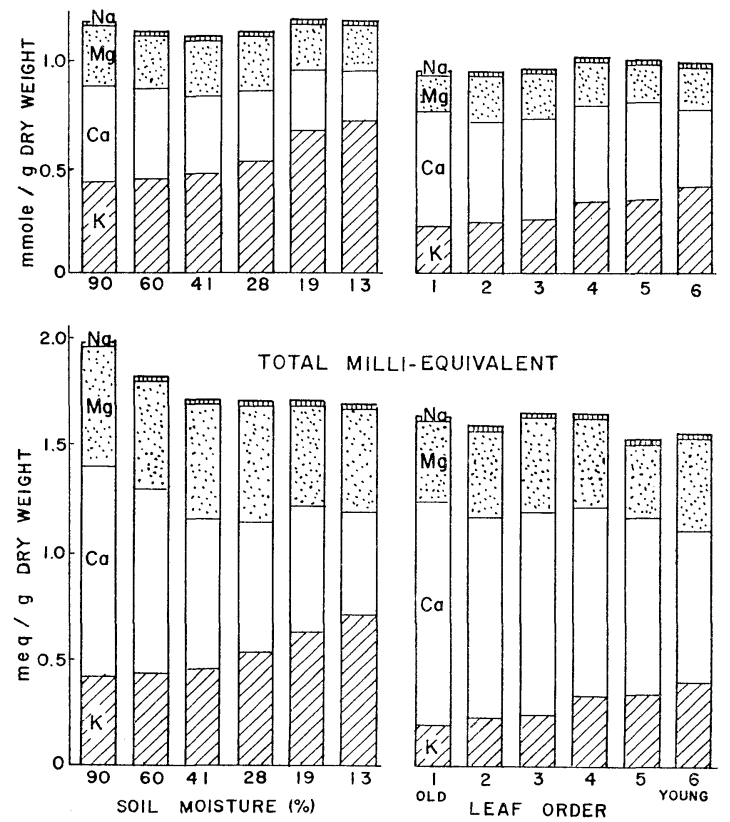

Fig. 4. Variation of total millimoles (upper) and total milliequivalents (lower) of cations of cowpea leaves in reference to the cultural soil moisture (left) and to the leaf age (right). 
in magnesium and sodium contents. The sum of cations is shown in Fig. 4. The total milliequivalents and the total millimoles of cations show little variation with leaf ageing.

As the plants of a $13 \%$ plot have 5-6 leaves and are expectedly smaller than those of a $90 \%$ plot which have 7-11 leaves, it is doubtful whether the drought condition of soil causes the plants to remain in an immature state, or causes them to rejuvenate. To throw light on this problem, the leaves of each test plant were classified into three groups, upper, middle, and lower on the basis of leaf order, each group having an equal number of leaves. The mineral contents of these samples in relation to the soil moistures are shown in Fig. 5. A similar tendency as above was seen in

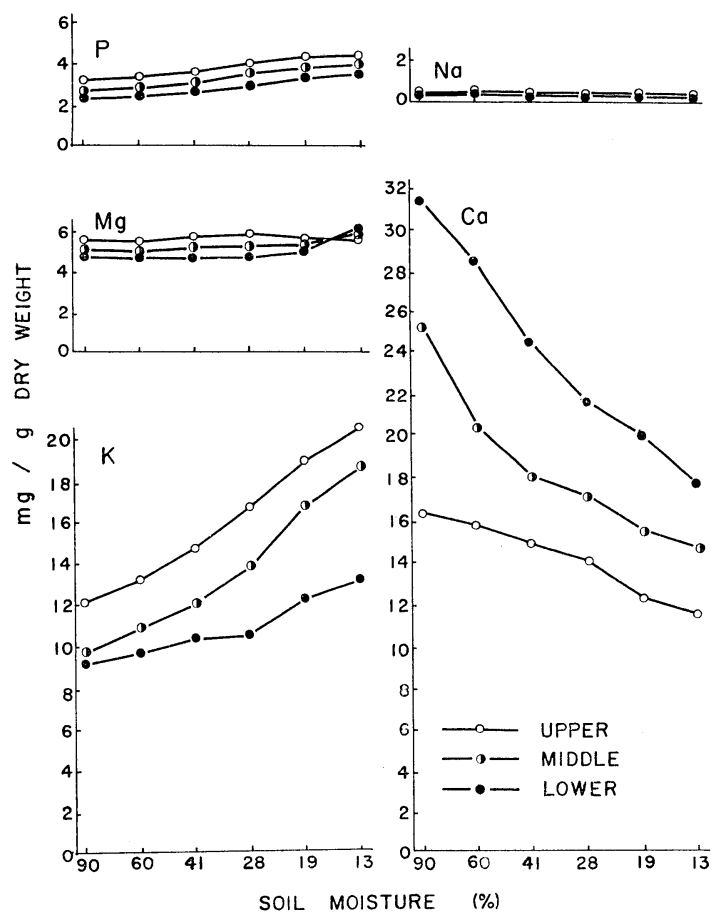

Fig. 5. Mineral content of cowpea leaves located on upper, middle, and lower parts of the plant stem.

variation of mineral content of leaves with the dryness of soil or the ageing of leaves. The lower leaves from a $13 \%$ plot contained $13.3 \mathrm{mg}$ potassium per $1 \mathrm{~g}$ of dry matter, while the upper leaves from a $90 \%$ plot gave $11.8 \mathrm{mg}$. A similar relation was also seen in phophorus content. From these results it may be assumed that the dwarf plant in a $13 \%$ plot is not merely a survivor of young parts of the plant which might be caused by the retardation of maturing of the leaves, but is an accommodated form to the dryness of the soil by increasing potassium and phosphorus content in the leaves.

\section{Discussion}

It was reported that the potassium contents of tomato ${ }^{4,5)}$ and maize plants ${ }^{6)}$ cultivated in dry soil are higher than those in moderate moisture soil. In contrast 
with this, the lower potassium content in dry condition was observed on wheat, oats and barley ${ }^{7)}$, tobacco plant ${ }^{8)}$, snap beans ${ }^{9)}$, tomato ${ }^{10)}$, and peach and apple etc. ${ }^{11}$ In young Hass avocado trees, however, no definite correlation between soil moisture and potassium content of the leaves was detected ${ }^{12)}$. Thus it appears difficult to determine with certainty whether the variation of potassium content of plants correlates with soil moisture changes. This uncertainty may be the result of difference of plant species, because a similar uncertainty was reported even among a few varieties of one beet species ${ }^{13)}$. In the present experiment both rape and cowpea showed higher potassium content under drought conditions than under moderate soil moisture conditions.

Lower calcium content under dry conditions was reported for wheat, oats, and barley $^{7)}$, but higher content for snap beans ${ }^{9)}$, and celery ${ }^{14)}$. In field experiment the seasonal variation in concentration of calcium was inverse to that of potassium in cacao leaves, and the effect of irrigation was small, but it decreased the levels of calcium, potassium, and magnesium in the leaves ${ }^{15)}$. In the present study both rape and cowpea showed a decrease of calcium content as soil water decreased. Furthermore, the $\mathrm{K} / \mathrm{Ca}$ ratio was not in agreement among investigators: Stocker ${ }^{16,{ }^{17)}}$ reported the ratio was small as the result of increased absorption of bivalent ions in dry soil; Simonis ${ }^{18)}$ however could not confirm this finding in broad beans, but Werk ${ }^{19)}$ reported the $\mathrm{K} / \mathrm{Ca}$ ratio apparently increased.

It is a common knowledge that calcium ion shrinks protoplasm and potassium ion to the contrary causes swelling. Fukuda ${ }^{20)}$ proposed that water uptake by the plant cell probably occurs principally by the swelling of protoplasm. Steward et al. ${ }^{21)}$ noted that potassium salts stimulate and calcium salts depress the water absorption of potato tissue and suggested that actively metabolizing cells may absorb water with little relation to conventional osmotic theory but rather more in relation to metabolic processes. Potassium is said to accumulate in the young part of a plant where the metabolic activity is high, maintaining the tissue in swelled state by increase of water-holding capacity. From the facts that in the younger leaves potassium content is higher and drought tolerancy is greater than those in the older leaves in rape plant, and that a similar correlation was seen between plants cultured in dry soil and wet one, it is conceivable that potassium ion plays an important role in waterabsorption or water-holding in plant cells.

Phosphorus content was reported to be smaller in dry plots than wet ones ${ }^{4,5,7,9,10,11)}$, but according to the other investigators it was on the contrary higher in dry soil ${ }^{6)}$. In the present investigation the phosphorus content increased gradually as the soil moisture decreased.

As to the magnesium content there has been also two opposite findings, one showing an increase with drying of soil ${ }^{7)}$, the other showing a decrease ${ }^{10)}$. The author observed the magnesium content to increase slightly in rape but cowpea showed very little variation with respect to drought conditions.

On the other hand, comparing the mineral content of leaves with respect to leaf age, the calcium content was reported to be larger in the older leaves than the younger ones of strawberry ${ }^{22)}$, tobacco plant ${ }^{23)}$, and grasses ${ }^{24)}$. Potassium content was reported to be larger in immature leaves than the mature ones of grasses ${ }^{24)}$, and tomato ${ }^{25)}$. It was reported that the potassium and phosphorus content decreased and calcium and magnesium content increased with the ageing of leaf on several 
plants_-apple, blue berry, citrus, fig, peach, pine, and vegetables ${ }^{26)}$. The author's data are in agreement with these reports.

It was reaffirmed in this investigation that the total milliequivalents of calcium, magnesium, and potassium contained in crops were fairly constant notwithstanding the relative changes of values of each element ${ }^{27,28)}$.

As described above, the change of mineral content of plant caused by soil moisture deficit is similar to the variation of mineral content of leaves at different ages. From the observations that the younger leaves wilt less easily than the older ones in a plant body when the soil drys, and that plants cultured under dry conditions become more tolerant to drought than those in wet soil, one of the common characteristic differences between young and old leaves and between plants with various drought tolerances, developed under dry or wet conditions, seems to be the mineral contents.

\section{Summary}

A comsarison of mineral content was made between leaves of different ages and between plants cultured in various soil moisture conditions using rape (Brassica rapa) and cowpea (Vigna sinensis) as the plant materials.

The younger leaves and the whole plant cultured in dry soil contain more potassium and a little more phosphorus but less calcium than the older leaves or the whole plant in wet soils, respectively. Magnesium and sodium contents showed, however, very little differences in these comparisons. It may be said that the development of drought tolerance in a plant through drought hardening seems to relate with some features similar to those in younger leaves of the plant with respect to mineral contents.

The sum of cations, total millimoles and total milliequivalents, was usually maintained at almost constant levels in one experimental series.

The author wishes to express his gratitude to Mr. Toshio Okimoto for taking part in some of the experiments.

\section{References}

1) Takaoki, T., J. Sci. Hiroshima Univ. Ser. B. Div. 2, 9: 209 (1962). 2) Nakamura, M., J. Agr. Chem. Soc. Japan 24: 1 (1950). 3) Chen, P. S., Toribara, T. Y., and Warner, H., Anal. Chem. 28: 1756 (1956). 4) Emmert, E. M., and Ball, F. K., Soil Sci. 35: 295 (1933). 5) —, ibid 41: 67 (1936). 6) Miller, M. F., and Duley, F. L., Missouri Agr. Expt. Sta. Bull. 76: 36 (1925). 7) Greaves, J. E., and Carter, E. G., J. Biol. Chem. 58: 531 (1923). 8) McMurtrey, J. E., Bowling, J. D., Brown, D. E., and Engle, H. B., J. Agr. Res. 75: 215 (1947). 9) Thomas, W., Mack, W. B., and Cotton, R. H., Proc. Am. Soc. Hort. Sci. 40: 531 (1942). 10) —- - - and - ibid 42: 535 (1943). 11) Hibbard, A. D., and Nour, M., ibid 73: 33 (1959) 12) Embleton, T. W., Garber, M. J., Jones, W. W., and Richards, S. J., ibid 71: 310 (1958). 13) Wimmer, G., Sammet, K., and Lesch, W., Z. Wirtschaftsgruppe Zuckerind. 94: 2 (1944). 14) Cannell, G. H., Tyler, K. B., and Asbell, C. W., Proc. Am. Soc. Hort. Sci. 74: 539 (1959). 15) Burridge, J. C., Lockard, R. G., and Acquaye, D. K., Ann. Bot. 28: 401 (1964). 16) Stocker, O., Naturwiss. 34: 362 (1947). 17) —_, Planta 35: 445 (1947). 18) Simonis, W., ibid 40: 313 (1952). 19) Werk, O., Flora 141: 312 (1954) 20) Fukuda, Y., Jap. J. Bot. 16: 181 (1958). 21) Steward, F. C., Stout, P. R., and Preston, C., Plant Physiol. 15: 409 (1940). 22) Lineberry, R. A., and Burdhart, L., ibid 18: 324 (1943). 23) Kasai, Z., and Konishi, S., Mem. Res. Ins. Food Sci. Kyoto Univ. No. 20: 14 (1960). 24) Pritchard, 
G. I., Pigden, W. J., and Folkins, L. P., Can. J. Plant Sci. 44: 318 (1964). 25) Arnon, D. I., and Hoagland, D. R., Bot. Gaz. 104: 576 (1943). 26) Smith, P. F., Ann. Rev. Plant Physiol. 13: 81 (1962). 27) Hunter, A. S., Soil Sci. 67: 53 (1949). 28) Hashimoto, T., J. Sci. Soil and Manure, Japan 26: 139 (1955).

\section{摘 要}

高沖 武：高等植物における葉齢と耐乾性との関係 I. 無機物含有量

栽培土塞の含水量の差抢よび葉齢の 差によるタイサイと飼料ササゲの葉の無機物含有量の相違を此較し

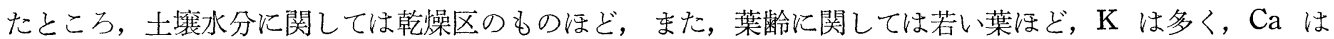
少なく，P は僅かに多く， Mg， Na には差が認められなかった．植物が乾燥に順致するにつれて獲得する 性質は無機物含有量に関する限り若い細胞の性質を帯びてくるものと考えられる.

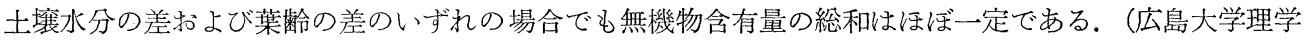
部植物学教室) 